\title{
Mediation as an Alternative to Underage Marriage Dispute Resolution
}

\author{
Mia Hadiati ${ }^{1,}$ Moody R. Syailendra ${ }^{2}$ Luthfi Marfungah $^{3}$ \\ ${ }^{1}$ Law Faculty of Universitas Tarumanagara Jakarta, Indonesia, Email: miah@fh.untar.ac.id \\ ${ }^{2}$ Law Faculty of Universitas Tarumanagara Jakarta, Indonesia,Email: moodys@fh.untar.ac.id \\ ${ }^{3}$ Law Faculty of Universitas Tarumanagara Jakarta, Indonesia, Email: luthfimarfungah10@ gmail.com
}

\begin{abstract}
Underage Marriage is a marriage conducted not in accordance with the provisions of Law No. 1 of 2974 concerning Marriage (Marriage Law). The Marriage Law regulates the age limit for carrying out marriages, namely Men Nineteen (19) Years and Women Sixteen (16) Years. There are many factors that cause the prevalence of Underage Marriage in Indonesia. Underage marriage can lead to disputes in the household due to the still unprepared age of adolescence in the face of marriage. Mediation as one of the Alternative Dispute Resolution can be used in resolving disputes that occur in underage marriages. The method used in this study is normative research. Normative legal research is legal research that uses primary data. This article will discuss the role of mediation in resolving disputes that occur in marriages performed by underage couples. Through this article, it is hoped that the mediating role in resolving household disputes can be known.
\end{abstract}

Keywords: Mediation, Dispute, Marriage

\section{INTRODUCTION}

Formal verification can reveal the unexposed defects in a According to Law No. 1 of 1974, marriage is an inner and outer bond between a man and woman with the aim of forming a happy and eternal family based on the One Godhead. Marriage is a sacred bond between socially recognized men and women to build families, legalize / justify sexual relations, legitimize and raise children, and share roles between each partner. The existence of marriage is expected that husband and wife can bring happiness and permanence in carrying out the marriage, so that in carrying out the marriage requires maturity and responsibility both physically and mentally from the parties who carry it out. Therefore, in Indonesia it is stipulated by Law No. 1 of 1974 concerning Marriage, Limit the age of marriage. Even so, in fact there are still many marriages carried out by minors, or can be said to be child marriages.

Article 7 paragraph (1) Law No. 1 of 1974 stipulates that marriage can be carried out if the male has reached the age of 19 (nineteen) years and the woman is 16 (sixteen) years old, and fulfills the specified marriage requirements. These requirements include, to carry out a marriage, a person who has not reached the age of 21 (twenty one) years must obtain prior permission from both parents. Minister of Religion Regulation No. 11 of 2007 concerning Marriage Registration in Chapter IV
Article 7 says, "If a prospective bride has not reached the age of 21 (twenty one) years, must get written permission from the parents". This permit is mandatory because at that age, the parties who will carry out the marriage are still considered to need guidance and supervision from their parents / guardians. In carrying out the marriage for the bride and groom who are not yet 21 (twenty one) years old, the parent / guardian must sign a clear name and name, so that the permit is used as the basis for the $\mathrm{PPN} /$ headmaster that the bride and groom have received permission / blessing from their parents . Another case if the two brides are more than 21 (twenty one) years, then the bride and groom can carry out a marriage without permission from parents / guardians. Candidates for a bride when married in Islam, then her parents are the guardian and the person who will marry her. Therefore permission and parental blessing is certainly a very important thing because it will be related to one of the pillars of marriage, namely the existence of a guardian of marriage.

Child marriage in Indonesia itself still causes a lot of controversy and problems in the community because there are different perspectives. The conflict between legal law is where the law legally states that it is legal for women who are married at the age of 16 as long as they get permission from their parents, and the right of the child to declare someone 18 years and under is a child who should still need guidance, education and supervision from parents. Until now, there is no meeting point for girls aged $16-18$ years. 
There are many factors that cause a lot of child marriage in Indonesia. For example religious factors and the view of the people who marry their children at the age of children (underage) is to avoid adultery. The involvement of formal and non-formal institutions that legalize child marriages as part of a particular community culture also contributes to the occurrence of underage marriage. Other factors that can be the cause of the marriage of minors are poverty. As a result of poverty, many parents marry off their children so that the parents responsibility in spending their children is lost [1] .

One of the main goals in forming a household is to build a family, feel love and affection among a married couple. The initial life of a household in general will feel love, affection, caring, and happiness. But over time, problems will arise in the household which results in the loss of feelings of love and affection between husband and wife. This can lead to complicated problems that are difficult to resolve by a married couple as a result of the lack of readiness and maturity that a married couple has due to being too young. Things like disputes, infidelity, etc. cause the household to fall apart [2]. Mediation is one of the many Alternative Dispute Settlements that are widely used in resolving disputes that arise in people's daily lives. Mediation is considered capable of resolving problems that exist in society quickly and effectively.

Mediation is a peaceful settlement of disputes. Mediation is widely used in Indonesia to solve problems within the household. Through this research, it is expected to be able to find out the mediating role in resolving household disputes, especially in households that carry out underage marriages. This research was conducted in several regions to find out the role of mediation in resolving disputes within households.

\section{PROBLEM FORMULATION}

Based on the description of the background above, as for the formulation of the problem to be examined is, What is the role of mediation in resolving disputes in underage marriage?

\section{RESULT AND ANALYSIS}

Young marriage is said to be one of the terms that are not directly included in the family planning category. Family planning at a young age when viewed is the target of the younger generation. By targeting young people it is recommended that the younger generation postpone marriage until the age is considered mature enough in various aspects to carry out a marriage. When looking at one's physical and spiritual health, it is concluded that the ideal age for carrying out a marriage in the community is if it covers the adult category physically, mentally and emotionally.

Family as the smallest community unit consisting of father, mother and child. Families can be formed if there is a bond of love between a man and an adult woman who is inaugurated with marriage, according to the marriage of the religion and the applicable law [3]. As a legal umbrella for marriage, the government seeks to accommodate these needs by issuing Law No. 1 of 1974 concerning marriage, hereinafter referred to as Law No. 1 Year 1974. Law no. 1 Year 1974 states that to form a family must be prepared carefully including couples who will form a family must be mature, both biologically and pedagogically or responsibly. So that later it will bring birth and inner bonds between men and women with the aim of forming a sakinah, mawaddah, and warohmah family [4].

In terms of guaranteeing legal certainty, all matters relating to marriage that occur before this Law takes effect, which are carried out according to existing law are valid. Likewise, if there is something about this Law that does not regulate, the existing provisions apply (retroactively). Regarding marriage, the main purpose of marriage as stated in Law No. 1 Year 1974 is forming a happy and eternal family. To create a happy and lasting family, husband and wife need to help and complement each other so that each can develop his personality to help and achieve spiritual and material well-being (a harmonious family) [5]. If referring and reviewing Law No. 1 of 1974 states that a marriage is legal if carried out according to the law of each religion and its beliefs and besides that, each marriage must be recorded according to the applicable laws and regulations and according to the religion he believes. Recording of each marriage is the same as important events in a person's life, such as birth, death which are stated in Certificates, an official certificate which is also included in the recording [6].

Regarding marriage registration, basically Law No. 1 Year 1974 adheres to the principle of monogamy [7].The point is this monogam principle is if desired by the concerned, because the law and religion of the concerned permit, a husband can have more than one wife. Hoowever, the marriage of a husband with more than one wife, even though it is desired by the parties [8]. concerned, can only be done if it is fulfilled by certain conditions and decided by the Court [8].

Besides that, Law No. This year 1 of 1974 adheres to the principle, that the prospective husband and wife have cooked (ready) their soul to be able to get married, so that they can realize the purpose of marriage well without ending in divorce and getting good and healthy offspring. Thus to overcome the end of divorce and get a good and healthy offspring, marriage must be prevented among prospective underage husband and wife. Besides that, marriage at an early age also has a relationship with 
population problems. In fact the population regarding a lower age limit for a woman to marry results in a higher birth rate. In connection with that, Law No. 1 of 1974 determines the age limit for marriage for both men and women, is 19 (ninteteen) years for men and 16 (sixteen) years for women [9].

From the law above, it is clear, that marriage and all its provisions have been packaged and arranged so well, so that marriage must be carried out according to the existing provisions. However, the actual marriage that takes place where the prospective partner is still below the age limit is included in early marriage, because the age of the prospective partner is included in the category of adolescents. However, in many cases, many are married at a young age. Pardoko stated that the factors that can make the reason for the marriage of minors are as follows: [10].

1. Lack of awareness of socialization regarding Law No. 1 of 1974 which guarantees rights and women, caused partly due to low literacy and education levels, especially in rural areas that are less affordable by communication channels;

2. The difficulty of the low social-economic condition of the parents tends to be the reason for marrying their daughters at a young age.

Thus in the opinion of the author, the existence of the causes of early age shows that one's education level, which includes, the narrowness of employment, due to the provision of inheritance, tradition / culture, and the low interest of parents to send their children to higher levels can affect the occurrence of women's marriages young age. If reviewed more in terms of health, especially women. In the opinion of the author for women (adolescents) who marry young will be at high risk because marriage at a young age encourages high maternal and child mortality.

In addition, early marriage can cause disputes in the perpetrators' households. Age that still tends to teenagers makes maturity imperfect and has emotions that tend to be difficult to control and unstable. Before the age of 21, a teenager's mentality is not fully ready to get married. Because, at that age the learning process of adolescents into adult individuals is not yet complete. The desire to learn and look for identity still has a strong influence on adolescents [11]. As a result, arguments due to disputes between husband and wife are unavoidable. Endless quarrels will have a direct impact on the household, and often there is violence in the fighting that occurs. Mental unpreparedness is also a factor in the emergence of disputes in the household, in addition to the unpreparedness in providing support also encourages disputes within the household that occur due to early marriage.

Of course, disputes or disputes within the household are not expected to occur. If it happens, surely the parties who are in it want to solve the problem properly and in a short time, so that there are no more complicated problems. In resolving disputes, not all parties can solve them quickly and well. The number of desires between the two parties causes dispute resolution to be done quickly and easily. Moreover, if a dispute occurs within a household that carries out an early marriage, mental immaturity and high desire can be a factor that causes difficulty in resolving disputes by a husband and wife. This is where the dispute resolution model is quickly and easily needed.

Mediation is an alternative dispute resolution that can be used. Mediation provides an opportunity for the parties to the dispute to play a role in resolving disputes with the help of third parties acting as mediators (mediators). The principle adopted by this is a win-win solution, so that no party wins or loses in resolving disputes. Mediation will provide maximum results if the parties commit well in resolving disputes. including prioritizing positive thoughts offered by mediators. This equality of principles is needed so that all parties are not trapped in selfish feelings and feel most righteous. All parties must have the determination to agree to end the dispute and find an accurate solution that is mutually beneficial, so that all parties are bound and can be carried out peace material. The material for peace is written in the form of letters or minutes and has a strong legal basis. Since 2003, the Supreme Court has integrated mediation in litigation processes in the civil sector through Supreme Court Regulation No. 2 of 2003, then Supreme Court Regulation No. 1 of 2008, and was finally refined through Supreme Court Regulation No. 1 of 2016. Through these regulations, Mediation procedures in the Court which is part of the civil procedural law and is expected to strengthen and optimize the functions of the judiciary in resolving 
disputes[12].

Mediation can also be done outside the court, in Andir Subdistrict, Bandung, the Andir District Office of Religious Affairs (KUA) has become a Mediator in early marriage dispute resolution. The disputing parties came to the Andir District Religious Affairs Office, Bandung to ask the KUA Officer to be the Mediator in resolving the dispute faced. The Head of the KUA Andir District, Bandung also told the author that KUA Andir was ready with open arms to accept the people who came to ask for help in resolving household disputes.

Mediation means, mediates. The mediator is not in the position of a judge, who enforces his justice mind, nor draws binding conclusions like arbitration but empowers the parties to determine what solutions they want. The mediator encourages and facilitates dialogue, helps the parties clarify their needs and desires, prepares guidelines, assists parties in correcting differences of views and works for what the parties can accept in a binding settlement. If there is already a match between the parties to the dispute and a memorandum is made which contains the agreements that have been reached.

If we refer to the viewpoint of time and the results that can be achieved through mediation, there will be many benefits compared to if we go through litigation settlement. The mediator in carrying out the education will prioritize family values without going through various inefficient formal processes. The time taken to resolve dispute mediation is relatively fast because cases are examined and brokered by the mediator himself. In addition, mediation is also mediated by parties representing each of the litigants, so that the mediator knows the ins and outs of each party. In addition, the person appointed to be a Mediator has the capacity and authority that is highly respected, so that all decisions and advice for resolving household disputes are always received warmly by all parties both from the husband and family of the husband and wife and wife's family. All disputed household secrets remain confidential and are not open to the public and most importantly all the disgrace of the family or the disputing household is well maintained.

\section{CONCLUSION}

Based on the above description it can be concluded; Early marriage is basically marriage that is not carried out in accordance with the age limit determined by Law No. 1 of 1974 concerning Marriage (Marriage Law). According to the Marriage Law, the age limit for marriage is 19 years (male) and 16 years (female), for those who carry out marriages under this age the marriage is said to be a Underage Marriage. Under marriage can cause various problems in the future, one of which is a dispute between husband and wife. Disputes in the household can occur due to young age who do not have perfect maturity and emotions that are still unstable in facing household problems. In dealing with disputes, sometimes a husband and wife, especially those who are underage, cannot resolve the dispute properly, so an institution that can resolve disputes is needed.

Mediation, as one of the Alternative Dispute Resolution is considered able to be a way out in solving household problems. Mediation offers a win-win solution to the parties to the dispute, so it is considered capable of resolving disputes without any party being won or defeated. Mediation is also mediated by the Mediator who represents each party, so the mediator can find out the personal details of the parties. In addition, the Mediator is also chosen from people who are considered to have high authority and wisdom, so that all decisions and advice for resolving household disputes are always accepted openly by all parties, both from the husband and family of husband and wife and wife's family.

\section{REFERENCES}

[1] Amiur Nurudi (2004) Hukum Perdata Islam di Indonesia.

[2] Badan Pusat Statistik (2015) Perkawinan Usia Anak di Indonesia.

[3] Fuad M. Ritwan (2008) Membina Keluarga Harmonis.

[4] Hasbiyallah (2015). Cara Mengatasi Kejenuhan dalam Rumah Tangga : Keluarga Sakinah.

[5] Gede Widhiana Putra (2006) Mediasi.

[6] Iman Jauhari (2011) Penyelesaian Sengketa Rumah Tangga Di Luar Pengadilan Menurut Hukum Islam.

[7] Koes irianto (2004) Pelayanan Keluarga Berencana Dua anak cukup.

[8] Muachor Ali Muh (1982), Buku Pintar Keluarga Muslim.

[9] Tarkariwan Cahyadi (1997) Pernak-Pernik Rumah Tangga Islam: Tatanan dan Perayaannya Dalam Masyarakat.

[10]Rina Antasari (2013) Pelaksanaan Mediasi dalam Sistem Peradilan Agama (Kajian Implementasi 
Mediasi dalam Penyelesaian Perkara di Pengadilan Agama Kelas I A.

[11] Soedharyo Soimin (1992) Hukum Orang dan Keluarga

[12] Soemiyati (1982) Hukum Perkawinn islam dan Undang-undang Perkawinan (Undang-Undang No. 1 Tahun 1974 Tentang Perkawinan). 